Available online at: https://proceeding.researchsynergypress.com/index.php/rsfconferenceseries1

RSF Conference Series: Business, Management and Social Sciences

e-ISSN 2807-5803/ p-ISSN 2807-6699

Volume 1 Number 3 (2021): 390-401

\title{
MTI Website Quality Improvement as A Strategy to Increase Webometric Ranking
}

\author{
Agus Ristono', Dyah Rahmawati Lucitasari'1, Yuli Dwi Astanti', Berty Dwi Rahmawati', \\ Puji handayani Kasih' ${ }^{1}$ \\ ${ }^{1}$ Industrial Engineering Department, Faculty of Industrial Engineering, Universitas Pembangunan \\ Nasional "Veteran" Yogyakarta, Indonesia
}

\begin{abstract}
The website is one of the communication platforms used by a university to provide information, especially to students and generally to the public. In addition to increasing service satisfaction, improving the quality of the website is also one of the benchmarks for the quality of education in a university. Webometrics is one of the world-class university website ranking metrics. Webometrics has several metrics that can describe the quality of a website. The UPNVY MTI Department is one of the study programs at UPNVY, which is committed to participating in improving the university's webometrics ranking. To improve service quality and website ranking on webometrics, it is necessary to formulate a strategy to improve the website quality. This study conducts a SWOT analysis in order to design strategies that can be carried out to improve the quality of the MTI UPNVY website. The results showed that there were eight strategies that could be implemented. The most important strategy to be implemented is to establish a special team to manage the MTI UPNVY website on a regular and up-to-date.
\end{abstract}

Keywords: SWOT Analysis, Website, Webometrics

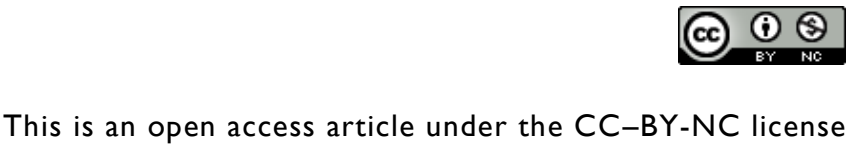

\section{INTRODUCTION}

Master of Industrial Engineering (MTI) is one of the master programs at the "Veteran" Yogyakarta National Development University (UPNVY). As the need for master's graduate increases, it encourages many universities to open master's study programs. This makes MTI UPNVY must continue to improve its quality and maintain its existence so that MTI UPNVY is known and becomes the choice of the people to continue their studies. One effort that can be made is using the website as a representative of the master program of MTI UPNVY so that the public gets the information they need.

Websites have an important role for an institution, including master's programs. Through the website, the public can get information about registration up to the tri dharma activities of higher education carried out in the study program. Therefore, a website must have advantages and reliability both in terms of speed and ease of access, up-to-date and accurate information, as well as an attractive appearance. The high competition in master's education makes the institutions improve the quality of their website management continuously. To support the improvement of the quality of higher education websites, university web rankings have emerged called webometrics.

Webometrics is a world-class university web ranking metric that aims to motivate institutions to have websites that accurately reflect the institution's activities. Quoted from the official website, https://www.webometrics.info/en, webometrics is a ranking method initiated by Cybermetrics Lab in

Corresponding author

Yuli Dwi Astanti, yulidwi.astanti@upnyk.ac.id

DOI: https://doi.org/10.31098/bmss.v1i3.352

Research Synergy Foundation 
2004. The Cybermetrics Lab is a research group belonging to the Consejo Superior de Investigaciones Científicas (CSIC), the largest public research institute in Spain. The ranking on webometrics is emphasized on the indicators of Presence (P), Visibility (V), Transparency (T) and

Excellence (E) (Aguillo et al., 2008). Reporting from the official website webometrics, currently UPNVY ranks very low, which is at number 168 in Indonesia.

Based on this description, to improve quality, maintain the existence of MTI UPNVY and help UPNVY institutions to improve their webometrics rankings, it is necessary to make improvements in the management of the UPNVY MTI website. The MTI UPNVY website page http://mti.fti.upnyk.ac.id/ is the official website that is hosted on the university website. Improving the quality of the MTI UPNVY website is expected to affect the increase in access to the university's website so that it can contribute to improving the university's webometrics ranking. In order to increase access to the MTI UPNVY website, research on quality improvement strategies is needed so that the website has advantages both in terms of speed, accuracy, up-to-date, and interest to visit. Research on improving the quality of institutional websites has often been carried out, including research by (Id et al., 2021), (Andike \& Dewi, 2017), and (Bahtiar 2018). all of these studies seek to improve university rankings on webometrics by improving the quality of the institution's website. The method used in all these studies is Gap analysis as well as statistical and descriptive analysis. This study will attempt to formulate an appropriate strategy to improve the quality of the MTI UPNVY website by applying the SWOT (Strength, Weakness, Opportunity, Threats) analysis method. SWOT will analyze external and internal factors so that appropriate strategies can be formulated for improving the quality of the MTI UPNVY website.

\section{RESEARCH METHOD}

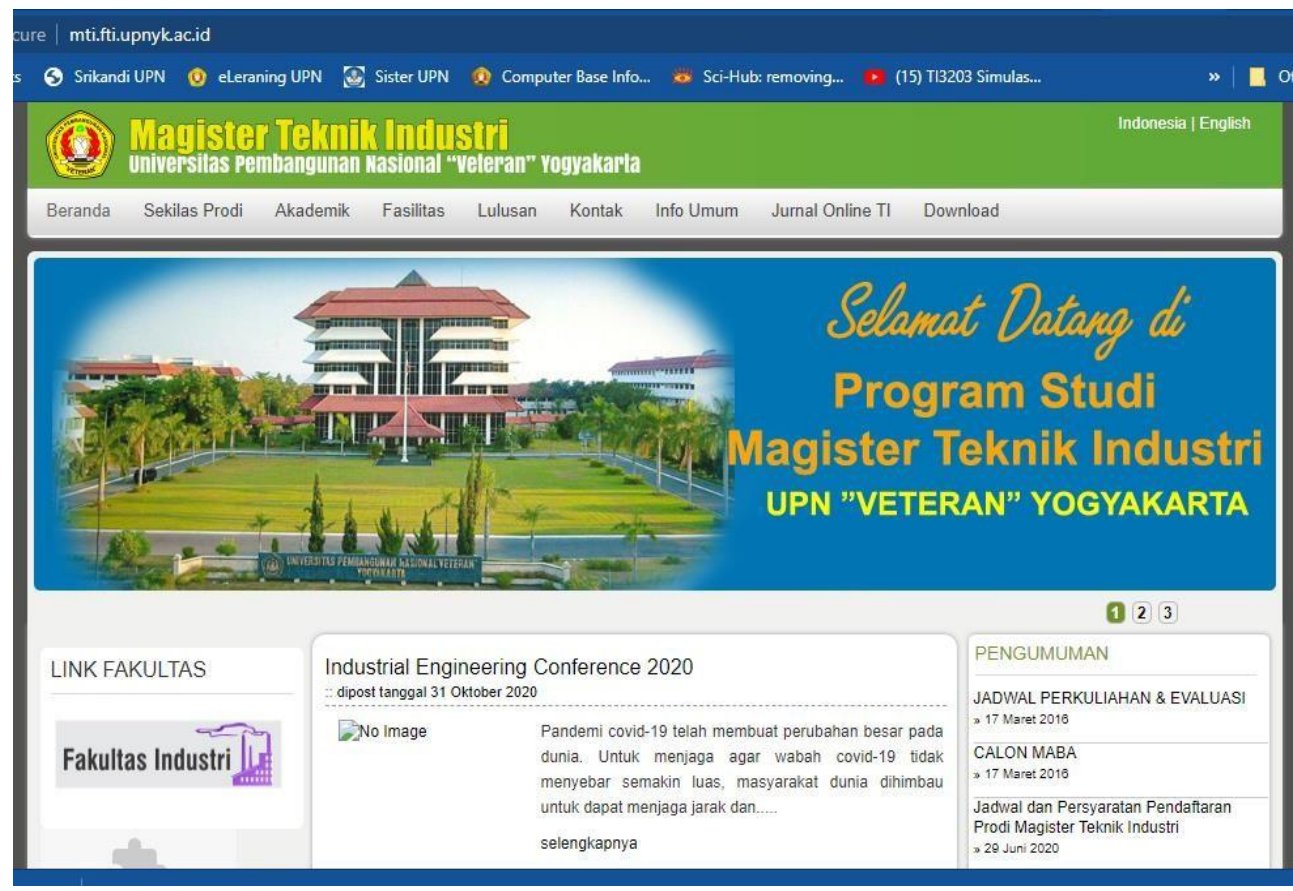

Figure1. Website MTI UPNVY 


\section{Research object}

This research focuses on the MTI UPNVY website with the website address http://mti.fti.upnyk.ac.id. Figure 1 depicts the current MTI UPNVY webpage. Based on the results of the visit to the web page, it is known that the MTI UPNVY web page already has various features and menus to make it easier for students and the public to access the information needed. However, when opened, some information is not up to date so that the number of visitors has decreased. Therefore, it is necessary to formulate a strategy to improve the quality of the website.

\section{Data collection}

The method of data collection in this study used the interview and benchmarking methods (comparing with other institutional websites). These two methods are implemented to obtain data about the current condition of the MTI UPNVY website, both internally and externally.

\section{Interview}

The interview is a face-to-face situation between the interviewer and the respondent which is intended to obtain the expected information and aims to obtain data about the respondent with a minimum of bias and maximum efficiency (Singh, 2002 in Hakim, 2013). Interviews were conducted with internal parties. Interviews were conducted with the Coordinator of the UPNVY MTI Study Program, website managers, and students as website users. Due to the Covid-19 pandemic, interviews were conducted online via whats app media to make it more flexible. Interviews were conducted to obtain internal information regarding the strengths and weaknesses of the MTI UPNVY website.

List of interview questions to internal parties consisting of Study Program Coordinators and website managers in general regarding the strengths, weaknesses, opportunities, and challenges in managing the website. While the list of questions asked to users, which has four important points, including 1) Questions to evaluate website content, website organization, and readability, 2) Questions to evaluate navigation and links, 3) Questions to evaluate the user interface design, 4) Questions to evaluate website performance and effectiveness (Chiew \& Salim, 2003).

\section{Benchmarking}

Benchmarking is a proactive approach that allows management to understand the ideal management of an organization to be used by its users and also can motivate management to focus attention on continuous improvement efforts and implement them (Wince, 2018). In essence, benchmarking seeks to improve and motivate change with the formulated strategy. In this study, benchmarking was carried out on four MTI program websites. Figure 2 is an example of a website for comparison in this study. Websites that are used for comparison include:

1. Website of Master degree of Institur Teknologi Sepuluh Nopember (ITS) Surabaya with the address https://www.its.ac.id/tindustri/akademik/program-studi/program-studi-s2/

2. Website Master degree of Industrial Engineering and Management of Institur Teknologi Bandung (ITB) with the address https://itb.ac.id/program-studi-magister-teknik-danmanajemen-industri

3. Website Master degree of Industrial Engineering of BINUS University with the address https://mie.binus.ac.id/

4. Website Master degree of Industrial Engineering of Kristen Petra University with the address http://mti.petra.ac.id/ 
From the entire website, it can be seen that there are two websites that have a website address under the website address of the institution. While the other two websites have their own addresses. This is the basis for choosing a comparison website. In addition, the selection of the website is based on the fact that the two institutes, ITS and ITB, are institutes that have become the benchmark for MTI's study programs so far. Meanwhile, the MTI BINUS and Petra websites also have their own advantages in managing their websites. By comparing the MTI website with four other better websites, it is hoped that it can help to improve the quality of the MTI UPNVY website.

\section{Webometrics}

In the era of globalization, where data can be accessed by anyone, anytime and anywhere making various sectors have opened access to the public, including the education sector. The emergence of webometrics encourages higher education to take the initiative to open access for transferring the knowledge and culture produced to people around the world. Webometric is a ranking of higher education institutions conducted every six months, which is independent, objective, free, open, multidimensional, and useful for assessing the performance of universities in the world (Id et al., 2021). Webometrics is easily accessible to anyone. On the official website with the following address https://www.webometrics.info/en, Webometric explains that there are four core indicators that are used as guidelines in assessing the performance of a university website. The four main indicators used as standards include:

1. Presence. Presence the number of web pages from the domain and all subdomains of the website. Presence is only worth $5 \%$ of the total value given to the webometrics ranking.

2. Visibility. Visibility is the sum of all external networks that provide backlinks to college websites. This visibility indicator has the highest rating score, which is $50 \%$.

3. Transparency or openness. Webometrics more often refers to it as Transparent Ranking. In this Transparency assessment, webometrics obtains data from Google Scholar. The score for this transparent ranking is $10 \%$.

4. Exellence atau scholar. Excellence is an assessment based on the number of scientific writings or works that fall into the $10 \%$ category of the most cited scientific works on Scopus.

\section{SWOT Analysis}

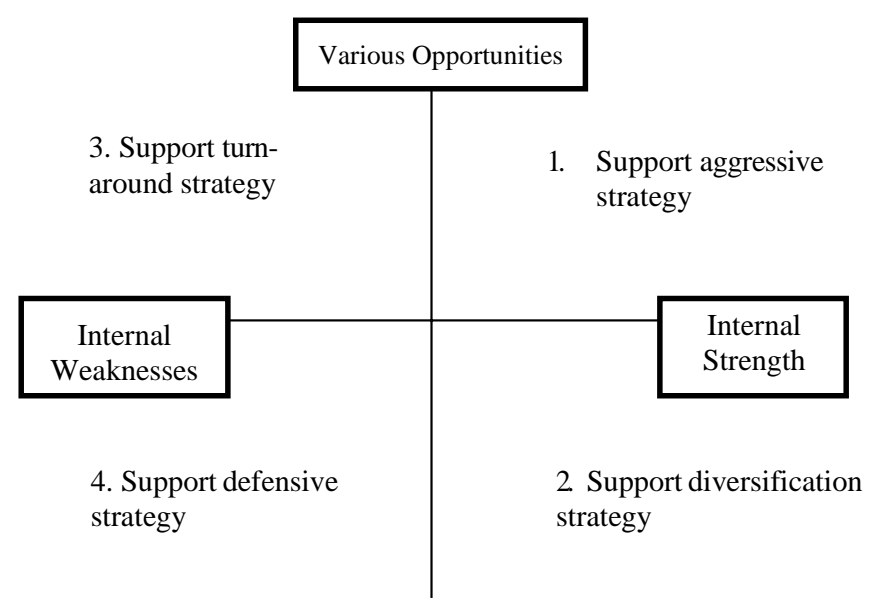

Figure2. SWOT Analysis Concept (Rangkuti, 2006) 
Rangkuti (2006), in his book, explains that SWOT analysis is the systematic identification of various factors to formulate corporate strategy. This analysis is based on the logic that can maximize strengths and opportunities but at the same time minimize weaknesses and threats.

Quadrant 1: A favorable situation means that there are opportunities and strengths to take advantage of existing opportunities. The strategy that must be applied in these conditions supports an aggressive growth policy.

Quadrant 2: A situation full of threats but still has internal strength. The strategy that must be applied is as follows using strength to take advantage of long-term opportunities by a diversification strategy.

Quadrant 3: This situation shows a great opportunity, but on the other hand, there are internal constraints. Strategies in this quadrant should try to minimize the internal problems so that they can seize better opportunities.

Quadrant 4: A very unfavorable situation due to various internal threats and weaknesses.

\section{FINDINGS AND DISCUSSION}

\section{Interview and Benchmarking Results}

Interviews were conducted with several parties, including the management of the Study Program and MTI UPNVY students. While benchmarking is executed by comparing the MTI UPNVY's website, with four other campus MTI websites, is better than the MTI website. Table 1 is a summary of the results of interviews that have been conducted.

Table 1. Interview Result Summary

\begin{tabular}{|l|l|}
\hline \multicolumn{1}{|c|}{ Informant } & \multicolumn{1}{|c|}{ Interview result } \\
UPNVY program & $\begin{array}{l}\text { The UPNVY website actually already has its own address as follows: } \\
\text { www.mti.fti.upnyk.ac.id. This website address is very strategic because it } \\
\text { is already hosted on the institutional website. Although in practice, there } \\
\text { are still many things that need to be improved, such as ease of operation } \\
\text { and delegation of authority in website editing. With this website domain, } \\
\text { MTI UPNVY can use it to introduce the MTI UPNVY program more } \\
\text { broadly. Basically, the MTI UPNVY department already has the desire } \\
\text { and idea to make optimal use of this website, but until now, the } \\
\text { management has not been optimal. Until now, in July 2021, the data and } \\
\text { information displayed are not up to date and less attractive. General } \\
\text { information such as registration, curriculum, lecturer profiles, and } \\
\text { others have not been updated yet. This is because, until now, there has } \\
\text { been no special team that manages the UPNVY website. The website is } \\
\text { still managed voluntarily by department administrators and several } \\
\text { lecturers. In addition, until now, there has been no awareness from those } \\
\text { with higher authority that the website is an important component for a } \\
\text { department because it is a representative of the MTI UPNVY department } \\
\text { in cyberspace. Especially in the current Covid-19 pandemic, the website } \\
\text { plays a very important role as the main guard in delivering information } \\
\text { to both internal (students) and external (general public) parties. The } \\
\text { website is also the main door for the promotion of the MTI UPNVY } \\
\text { department in attracting the attention of prospective new } \\
\text { students. }\end{array}$ \\
\hline
\end{tabular}




\section{MTI UPNVY students}

\begin{tabular}{|l|l|}
\hline \multicolumn{1}{|c|}{ MTI UPNVY } \\
students & $\begin{array}{l}\text { The MTI UPNVY website is quite good, easy to find and access. However, } \\
\text { when I visited, the appearance of the website was still not as expected. } \\
\text { The web page's appearance is uncomfortable to look at, both in terms of } \\
\text { color selection, images, and the placement of the menu. All of this causes } \\
\text { visitors (students) difficulty in finding the information they need. The } \\
\text { display can still be improved. The links on the website have not been } \\
\text { updated yet. In terms of content, the MTI UPNVY department website } \\
\text { should contain the latest information regarding the registration of } \\
\text { prospective students up to the procedure for graduating. The display } \\
\text { can still be improved. The links on the website have not been updated } \\
\text { yet. In terms of content, the MTI UPNVY department website should } \\
\text { contain the latest information regarding the registration of prospective } \\
\text { students up to the procedure for graduating. In addition to this } \\
\text { information, to support the learning process, a website must contain } \\
\text { research information and other latest information about scientific } \\
\text { progress. The advantages of the UPNVY industrial engineering master } \\
\text { study program also need to be highlighted on the website, and this is to } \\
\text { attract prospective new students in particular and provide information } \\
\text { about these advantages to the public in general. To make it even easier, } \\
\text { it would be better if there was direct chat access or contacts that could } \\
\text { be easily contacted to answer visitor questions (if any). }\end{array}$ \\
\hline
\end{tabular}

The benchmarking process is carried out by comparing the MTI website with four other websites that have advantages over the MTI UPNVY website. Based on the previous explanation, it is known that the two websites are MTI websites from superior state universities and become scientific barometers. The two universities are ITS and ITB. While the other two websites are websites from private universities that have good predicate according to the community. The universities are BINUS University and Petra Christian University. Therefore, in the summary of the benchmarking results, there will be two groups of websites. Table 2 describes the summary of benchmarking results.

Table 2. Benchmarking Result Summary

\begin{tabular}{|c|l|}
\hline \multicolumn{1}{|c|}{ Website } & \multicolumn{1}{|c|}{ Evaluation result } \\
\hline MTI of ITS and ITB & $\begin{array}{l}\text { The MTI ITS and ITB websites can be said that the two websites have } \\
\text { some similarities, so they will be made into one group. These two } \\
\text { websites are joined to the university's website, with a menu of } \\
\text { postgraduate programs. Especially for the MTI program, the } \\
\text { information displayed is only profiled information, registration } \\
\text { mechanisms, and facilities offered by the industrial engineering } \\
\text { master's program at the two universities. Although only the } \\
\text { information, it is up to date in accordance with the latest regulations. } \\
\text { In contrast to the undergraduate program, the MTI website has not } \\
\text { yet seen the latest information about activities at MTI. ITB and ITS } \\
\text { are campuses for alumni of industrial engineering majors in } \\
\text { Indonesia. Although various universities have established } \\
\text { postgraduate programs, these two state campuses will always have } \\
\text { enthusiasts. Therefore, the most important thing for prospective }\end{array}$ \\
\hline
\end{tabular}




\begin{tabular}{|c|l|}
\hline & $\begin{array}{l}\text { MTI students is general information related to registration, etc. In } \\
\text { terms of appearance, the ITS and ITB websites have an attractive } \\
\text { appearance and are quite eye-catching. Visitors are easy to find the } \\
\text { information they need; there are also contacts andsocial media that } \\
\text { can be used to ask questions directly. Information on the latest } \\
\text { activities, tri dharma activities, facilities, teachers, and others } \\
\text { following the undergraduate program, no one specifically discusses } \\
\text { this at the MTI level. }\end{array}$ \\
\hline $\begin{array}{c}\text { MTI BINUS University } \\
\text { (Petra) University }\end{array}$ & $\begin{array}{l}\text { Unlike the previous two state universities, the MTI BINUS and Petra } \\
\text { websites have their own website addresses. BINUS and Petra are } \\
\text { private universities that have quite a lot of demand in Indonesia, and } \\
\text { both universities have excellent accreditation for the Industrial } \\
\text { Engineering program. In addition, it can be seen from the } \\
\text { appearance of the website with up-to-date activities showing the } \\
\text { activeness of the MTI program. In addition to general and important } \\
\text { information about prospective student registration, these two } \\
\text { websites are like undergraduate program websites that display } \\
\text { active and up-to-date MTI student activities. The website is also } \\
\text { equipped with information about research and publications from the } \\
\text { academic community and even information about careers which are } \\
\text { generally found on undergraduate program websites. In terms of } \\
\text { appearance, the BINUS website has a better appearance than Petra. } \\
\text { The BINUS website is easy to access, light, and quite eye-catching. } \\
\text { While Petra has a pretty heavy look at the beginning, this is because } \\
\text { of the large image or background. Both websites provide easy-to- } \\
\text { access live chat links and social media addresses. }\end{array}$ \\
\hline
\end{tabular}

\section{SWOT Analysis}

After collecting data through interviews and benchmarking, the next step is to conduct a SWOT analysis. Tables 3 and 4 are tables of internal and external strategic factors or often referred to as IFAS (Internal Strategic Factor Analisis Summary) and EFAS (Eksternal Strategic Factor Analisis Summary).

Table 3. SWOT Analysis (IFAS)

\begin{tabular}{|c|l|c|c|c|}
\hline \multicolumn{5}{|c|}{ Internal Strategy Factor } \\
\hline $\begin{array}{c}\text { Strength } \\
\begin{array}{c}\text { Already have a website } \\
\text { with the } \\
\text { official university address }\end{array}\end{array}$ & 0,130 & 4 & 0,518 & $\begin{array}{c}\text { Maintain and always coordinate } \\
\text { with } \\
\text { the university }\end{array}$ \\
\hline $\begin{array}{c}\text { Website is easy to } \\
\text { access and operate }\end{array}$ & 0,138 & 3 & 0,415 & $\begin{array}{c}\text { There is a need for periodic } \\
\text { maintenance and management of } \\
\text { the } \\
\text { website }\end{array}$ \\
\hline $\begin{array}{c}\text { The commitment of the } \\
\text { head of the industrial } \\
\text { engineering master's } \\
\text { program department to } \\
\text { improve the quality of the } \\
\text { website }\end{array}$ & 0,181 & 2 & 0,361 & $\begin{array}{c}\text { It is necessary to take real } \\
\text { steps to realize the work } \\
\text { program of the industrial } \\
\text { engineering master's program } \\
\text { department related for } \\
\text { improving the quality of the }\end{array}$ \\
\hline
\end{tabular}


RSF Conference Series: Business, Management and Social Sciences, Vol. 1 (3), 390-401

MTI Website Quality Improvement as A Strategy to Increase Webometric Ranking

Agus Ristono, Dyah Rahmawati Lucitasari, Yuli Dwi Astanti, Berty Dwi Rahmawati, Puji handayani Kasih

\begin{tabular}{|c|c|c|c|c|}
\hline & & & & website \\
\hline $\begin{array}{l}\text { Various activities and } \\
\text { scientific works that } \\
\text { deserve to be published } \\
\text { on the website }\end{array}$ & 0,262 & 3 & 0,786 & $\begin{array}{l}\text { Socialization and archiving of } \\
\text { outputs and activities of the } \\
\text { academic community regularly to } \\
\text { be published } \\
\text { on the website }\end{array}$ \\
\hline \multicolumn{3}{|c|}{ Sub Total Score Weighting } & 2,081 & \\
\hline Weakness & Weight & Rating & Score & Recommendation \\
\hline $\begin{array}{l}\text { There is no special team } \\
\text { for website management }\end{array}$ & 0,039 & 3 & 0,118 & $\begin{array}{c}\text { Submission for the procurement } \\
\text { of assigned educational staff } \\
\text { where one } \\
\text { of their duties includes managing } \\
\text { the website }\end{array}$ \\
\hline $\begin{array}{l}\text { Website content is not up } \\
\text { to date }\end{array}$ & 0,064 & 3 & 0,193 & $\begin{array}{c}\text { Make a regular schedule to } \\
\text { update the website and ensure } \\
\text { that information is always } \\
\text { updated on the } \\
\text { website }\end{array}$ \\
\hline $\begin{array}{l}\text { The appearance of the } \\
\text { website is not user } \\
\text { friendly and less } \\
\text { attractive }\end{array}$ & 0,087 & 3 & 0,26 & $\begin{array}{c}\text { Improve the appearance of the } \\
\text { website to make it more } \\
\text { attractive } \\
\text { and user friendly }\end{array}$ \\
\hline $\begin{array}{l}\text { Incomplete website } \\
\text { features }\end{array}$ & 0,099 & 2 & 0,199 & $\begin{array}{l}\text { Adding features to the website, } \\
\text { such as the chat feature, so that } \\
\text { management is faster and } \\
\text { responsive to students }\end{array}$ \\
\hline \multicolumn{3}{|c|}{ Sub Total Score Weighting } & 0,769 & \\
\hline Total Score & \multicolumn{4}{|c|}{2,850} \\
\hline
\end{tabular}

Table 3. SWOT Analysis (EFAS)

\begin{tabular}{|c|c|c|c|c|}
\hline \multicolumn{5}{|c|}{ External Strategy Factors } \\
\hline Opportunity & Weight & Rating & Score & Recommendation \\
\hline $\begin{array}{l}\text { Digitalization of education } \\
\text { where the teaching and } \\
\text { learning process is online }\end{array}$ & 0,093 & 2 & 0,187 & $\begin{array}{l}\text { The outbreak of the COVID- } \\
19 \text { pandemic has become } \\
\text { one of the things that } \\
\text { require the industrial } \\
\text { engineering master's } \\
\text { department to } \\
\text { provide services in the online } \\
\text { form }\end{array}$ \\
\hline $\begin{array}{l}\text { Increased public interest in } \\
\text { taking the MTI program so } \\
\text { that they will look for } \\
\text { information about MTI on } \\
\text { the internet }\end{array}$ & 0,159 & 3 & 0,476 & $\begin{array}{l}\text { The website is one of the } \\
\text { means of promotion of the } \\
\text { industrial engineering } \\
\text { master's program }\end{array}$ \\
\hline
\end{tabular}


RSF Conference Series: Business, Management and Social Sciences, Vol. 1 (3), 390-401

MTI Website Quality Improvement as A Strategy to Increase Webometric Ranking

Agus Ristono, Dyah Rahmawati Lucitasari, Yuli Dwi Astanti, Berty Dwi Rahmawati, Puji handayani Kasih

\begin{tabular}{|c|c|c|c|c|}
\hline $\begin{array}{l}\text { People are more aware of } \\
\text { technological advances and } \\
\text { are used to looking for } \\
\text { information } \\
\text { on search engines on the } \\
\text { internet }\end{array}$ & 0,173 & 3 & 0,518 & $\begin{array}{l}\text { Develop a strategy so that } \\
\text { the MTI website always } \\
\text { appears at the forefront of } \\
\text { search engines }\end{array}$ \\
\hline $\begin{array}{l}\text { Ease of information that } \\
\text { can be } \\
\text { used to improve the quality } \\
\text { of the website }\end{array}$ & 0,288 & 3 & 0,864 & $\begin{array}{l}\text { Continuously improve } \\
\text { website quality and } \\
\text { subcontract if needed }\end{array}$ \\
\hline \multicolumn{3}{|c|}{$\begin{array}{c}\text { Sub Total Score Weighting } \\
\end{array}$} & 2,045 & \\
\hline Threat & Weight & Rating & Score & Recommendation \\
\hline $\begin{array}{l}\text { A more attractive and well- } \\
\text { managed competitor's } \\
\text { industrial engineering } \\
\text { master's department } \\
\text { website }\end{array}$ & 0,049 & 4 & 0,195 & $\begin{array}{l}\text { Other campus websites can be } \\
\text { used as a reference for } \\
\text { improving the MTI website }\end{array}$ \\
\hline $\begin{array}{l}\text { The public's interest in } \\
\text { opening the website is still } \\
\text { low when looking for } \\
\text { information and } \\
\text { prefers to open social media }\end{array}$ & 0,058 & 3 & 0,174 & $\begin{array}{l}\text { Connecting the MTI } \\
\text { website with social media } \\
\text { belonging to the industrial } \\
\text { engineering master's } \\
\text { department (MTI) } \\
\text { program }\end{array}$ \\
\hline $\begin{array}{l}\text { Hacker and or virus } \\
\text { attacks the website }\end{array}$ & 0,083 & 3 & 0,249 & $\begin{array}{c}\text { Improve website security } \\
\text { system }\end{array}$ \\
\hline $\begin{array}{l}\text { Limited funds for website } \\
\text { quality improvement }\end{array}$ & 0,098 & 2 & 0,195 & $\begin{array}{l}\text { Budgeting and allocating } \\
\text { special funds to improve } \\
\text { website quality for } \\
\text { the promotion of the } \\
\text { industrial engineering master } \\
\text { program }\end{array}$ \\
\hline \multicolumn{3}{|c|}{$\begin{array}{l}\text { Sub Total Score Weighting } \\
\end{array}$} & 0,813 & \\
\hline Total Score Weighting & \multicolumn{4}{|c|}{2,858} \\
\hline
\end{tabular}

The results of the analysis of internal and external conditions can be obtained from the value of External Factor Evaluation (EFE) of 2.858 and Internal Factor Evaluation (IFE) of 2.850. Based on the internal and external matrix, it can be seen that the MTI UPNVY website is on Hold and maintain a position where the internal conditions are moderate and the external conditions are moderate. Therefore, the MTI program should carry out a website development strategy by utilizing the existing website so that it becomes better than the previous condition

Table 4. Internal - External Matrix

\begin{tabular}{|c|c|c|c|}
\hline \multicolumn{5}{|c|}{$\begin{array}{c}\text { Internal Factor } \\
\text { Evaluation }\end{array}$} \\
& Strong & Moderate & Weak \\
& $3,0-4,0$ & $2,0-2,99$ & $1,0-$ \\
& & II & 1,99 \\
\hline Strong & I & III & \\
\hline
\end{tabular}




\begin{tabular}{|c|c|c|c|c|}
\hline $3,0-4,0$ & $\begin{array}{l}\text { Grow } \\
\text { and } \\
\text { Build }\end{array}$ & Grow and Build & $\begin{array}{c}\text { Hold } \\
\text { and } \\
\text { Maintain }\end{array}$ & External \\
\hline $\begin{array}{l}\text { Moderate } \\
2,0-2,99\end{array}$ & $\begin{array}{l}\text { IV } \\
\text { Grow } \\
\text { and } \\
\text { Build }\end{array}$ & $\begin{array}{c}\mathrm{V} \\
\text { Hold and Maintain } \\
\text { (Maintain existing websites and } \\
\text { continue to } \\
\text { develop and improve the website's } \\
\text { quality) }\end{array}$ & $\begin{array}{c}\text { VI } \\
\text { Harvest } \\
\text { or } \\
\text { Drivest }\end{array}$ & $\begin{array}{l}\text { Factor } \\
\text { Evaluation }\end{array}$ \\
\hline $\begin{array}{c}\text { Weak } \\
1,0-1,99\end{array}$ & $\begin{array}{c}\text { VII } \\
\text { Hold } \\
\text { and } \\
\text { Maintain }\end{array}$ & $\begin{array}{c}\text { VIII } \\
\text { Harvest or Driver }\end{array}$ & $\begin{array}{c}\text { IX } \\
\text { Harvest } \\
\text { or } \\
\text { Drivest }\end{array}$ & \\
\hline
\end{tabular}

After analyzing internal and external factors and knowing the position of the MTI UPNVY website, the next step is to formulate a strategy. Table 5 is a SWOT analysis table for the MTI UPNVY website.

Table 5. SWOT analysis

\begin{tabular}{|c|c|c|}
\hline Internal & $\begin{array}{l}\text { Strength (S) } \\
\text { 1. Already have a website } \\
\text { with the official } \\
\text { university address } \\
\text { 2. Website is easy to } \\
\text { access and operate } \\
\text { 3. The commitment of the } \\
\text { head of the industrial } \\
\text { engineering master's } \\
\text { program department to } \\
\text { improve the quality of } \\
\text { the website } \\
\text { 4. Various activities and } \\
\text { scientific works that } \\
\text { deserve to be published } \\
\text { on the website }\end{array}$ & $\begin{array}{l}\text { Weakness }(\mathbf{W}) \\
\text { 1. There is no special } \\
\text { team for website } \\
\text { management } \\
\text { 2. Website content is not } \\
\text { up to date } \\
\text { 3. The appearance of the } \\
\text { website is not user } \\
\text { friendly and less } \\
\text { attractive } \\
\text { 4. Incomplete website } \\
\text { features }\end{array}$ \\
\hline $\begin{array}{l}\text { Opportunity (0) } \\
\text { 1. Digitalization of education } \\
\text { where the teaching and } \\
\text { learning process is online } \\
\text { 2. Increased public interest in } \\
\text { taking the MTI program so } \\
\text { that they will look for } \\
\text { information about MTI on } \\
\text { the internet } \\
\text { 3. People are more aware of } \\
\text { technological advances and } \\
\text { are used to looking for } \\
\text { information on search } \\
\text { engines on the internet }\end{array}$ & \begin{tabular}{l}
\multicolumn{1}{c}{ SO Strategy } \\
Develop a special team \\
to improve the quality \\
of the website and \\
update information \\
regularly and be \\
responsive to users \\
- Develop a strategy so \\
that the MTI website \\
always appears at the \\
forefront of search \\
engines
\end{tabular} & $\begin{array}{l}\text { WO Strategy } \\
\text { - Improving the quality of } \\
\text { existing human } \\
\text { resources specifically to } \\
\text { manage the website so } \\
\text { that it has better quality } \\
\text { - Officially using the } \\
\text { website as a source of } \\
\text { information and as a } \\
\text { teaching and learning } \\
\text { media during online } \\
\text { lectures }\end{array}$ \\
\hline
\end{tabular}




\begin{tabular}{|c|c|c|c|}
\hline & $\begin{array}{l}\text { Ease of information that can } \\
\text { be used to improve the } \\
\text { quality of the website }\end{array}$ & & \\
\hline $\begin{array}{l}3 . \\
4 .\end{array}$ & $\begin{array}{l}\quad \text { Threats (T) } \\
\text { A more attractive and well- } \\
\text { managed competitor's } \\
\text { industrial engineering } \\
\text { master's department website } \\
\text { The public's interest in } \\
\text { opening the website is still } \\
\text { low when looking for } \\
\text { information and prefers to } \\
\text { open social media } \\
\text { Hacker and or virus attacks } \\
\text { the website } \\
\text { Limited funds for } \\
\text { website quality } \\
\text { improvement }\end{array}$ & $\begin{array}{l}\text { - ST Strategy } \\
\text { Creating social media } \\
\text { accounts for the MTI } \\
\text { program, especially } \\
\text { those that are being } \\
\text { widely used by the } \\
\text { community and } \\
\text { connecting the website } \\
\text { with the social media } \\
\text { Budgeting and } \\
\text { allocating special } \\
\text { funds to improve } \\
\text { website quality for the } \\
\text { promotion of the MTI } \\
\text { program }\end{array}$ & $\begin{array}{l}\text { WT Strategy } \\
\text { - Improve the appearance } \\
\text { and add features to the } \\
\text { website to make it more } \\
\text { attractive and more } \\
\text { comfortable when used by } \\
\text { users } \\
\text { - Improved website } \\
\text { security from hacker } \\
\text { attacks }\end{array}$ \\
\hline
\end{tabular}

From the IFE matrix, it can be seen that the Strengths value of the MTI UPNVY website is 2.081 and Weaknesses are 0.769 (greater strength), Opportunities value is 2.045, and Threats is 0.813 (greater opportunity). This is a reference that the strategy that must be taken is a strategy of weakness and threats. Based on the SWOT matrix above, the MTI UPNVY website can use its strengths to seize the opportunities that exist. The way that the UPNVY MTI Program Department can be carried out is the development of a special team to improve website quality that regularly updates information and also be more responsive to users. The UPNVY MTI Program Department also needs to develop strategies so that the MTI website always appears at the top when searched using user engines. In this strategy, what is needed is the strength of the chairman's commitment to developing a special team that manages the website and ensures that it is not only easily accessible but also always appears on search engines so that it will affect the university's webometrics ranking.

\section{CONCLUSION AND FUTURE RESEARCH}

Based on the analysis that has been done, several points can be concluded. First, the condition of the MTI UPNVY website with an EFE value of 2.858 and an IFE of 2.850 is in a Hold and maintain a position where the internal conditions are moderate, and the external conditions are moderate. Based on the swot results, it can also be seen that the strength value (2.081), which is greater than the weakness (0.769), and the opportunity value (2.045), which is greater than the threats (0.813), becomes a reference that MTI can adopt the Strenght and Opportunities or SO strategy. Therefore, the MTI UPNVY website should carry out a development strategy on an existing website by committing to provide a special team that manages the website. In addition, to improve the university's webometrics ranking, it is necessary to formulate a strategy to increase the chances of the website appearing in every MTI-related search. This study only uses SWOT analysis to formulate a strategy for improving the quality of the MTI UPNVY website, and it would be better if further research adds an approach or method that can analyze problems and search for more in-depth solutions. 
RSF Conference Series: Business, Management and Social Sciences, Vol. 1 (3), 390-401

MTI Website Quality Improvement as A Strategy to Increase Webometric Ranking

Agus Ristono, Dyah Rahmawati Lucitasari, Yuli Dwi Astanti, Berty Dwi Rahmawati, Puji handayani Kasih

\section{ACKNOWLEDGMENT}

The authors acknowledge the support of Lembaga Penelitian dan Pengabdian Masyarakat (LPPM) Universitas Pembangunan Nasional Veteran Yogyakarta.

\section{REFERENCES}

Aguillo, I. F., Ortega, J. L., \& Fernández, M. (2008). Webometric ranking of world universities: Introduction, methodology, and future developments. Higher Education in Europe, 33(2-3), 233-244. https://doi.org/10.1080/03797720802254031

Andike, F., \& Dewi, A. O. P. (2017). Evaluasi Kualitas Website Institutional Repository Universitas Gajah Mada Berdasarkan Indikator Webometrics. Jurnal Ilmu Perpustakaan, 6(1), 11-20. https://ejournal3.undip.ac.id/index.php/jip/article/view/23018

Bahtiar, A. C. (2018). Kajian Webometrics Repositori Universitas Islam Negeri Sunan Kalijaga Yogyakarta.

Jurnal Perpustakaan Pertanian, 26(2), 77. https://doi.org/10.21082/jpp.v26n2.2017.p77-81

Chiew, T. K., \& Salim, S. S. (2003). Webuse: Website usability evaluation tool. Malaysian Journal of Computer Science, 16(1), 47-57.

Hakim, L. N. (2013). Ulasan Metodologi Kualitatif: Wawancara Terhadap Elit. Aspirasi, 4(2), 165172. https://jurnal.dpr.go.id/index.php/aspirasi/article/view/501

Id, I. D., Andriani, Y. I. daqiqil@lecturer. unri. ac. i., Mahdiyah, E., \& Al Aminuddin, A. A. (2021). Strategi TIK untuk Meningkatkan Peringkat Webometric Universitas Riau Menggunakan Metode GAP Analysis. Sistemasi, 10(2), 300. https://doi.org/10.32520/stmsi.v10i2.1213

Rangkuti, F. (2006). Analisis SWOT Teknik Membedah Kasus Bisnis. Gramedia Pustaka Utama.

Wince, E. (2018). Benchmarking dalam Manajemen Sebuah Perpustakaan. Tik Ilmeu: Jurnal Ilmu Perpustakaan Dan Informasi, 2(1), 23. https://doi.org/10.29240/tik.v2i1.435 